\section{Member Societies}

Recent information indicates that membership in National Societies affiliated to the EPS has increased by about $10 \%$ since last year.

The Polish Physical Society (Polskie Towarzystwo Fizyczne) has been accepted by Council as a Member according to Article $4 \mathrm{~b}$ of the Constitution as from 1 January 1972.

M. Soutif has been appointed President of the French Physical Society in succession to J. Friedel.

W. Buckel has been appointed President of the German Physical Society (DPG) in succession to K.E. Ganzhorn.

\section{Divisions}

The Atomic Physics Division held its first meeting in July at Reading, UK, and elected H. van Regemorter, Chairman, and G.W. Series, Secretary of the Division.

The Condensed Matter Division held the First European Conference on the Physics of Condensed Matter at Florence in September (see report on pp. 1-2 of this issue). A. Guinier was appointed as new Chairman of the Division.

\section{New Information Booklet}

A new edition of the EPS Information Booklet is in preparation. It will contain full details of the Society and up-to-date addresses of Members.

\title{
New Individual Ordinary Members
}

The following have been accepted as Individual Ordinary Members of the European Physical Society :

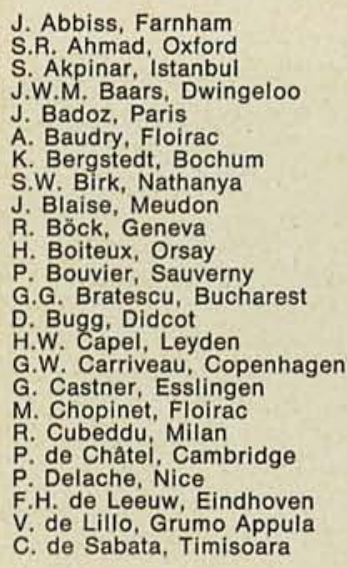

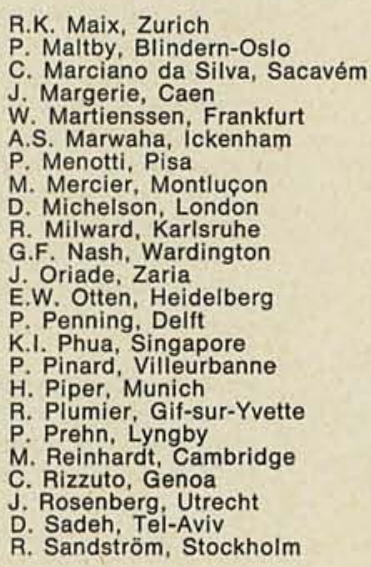

